\title{
A nematode in the mist: Scottnema lindsayae is the only soil metazoan in remote Antarctic deserts, at greater densities with altitude
}

\author{
Krzysztof Zawierucha ${ }^{1,4}$, Craig J. Marshall ${ }^{2}$, David Wharton ${ }^{3}$ \& Karel Janko $0^{4,5}$ \\ ${ }^{1}$ Department of Animal Taxonomy and Ecology, Faculty of Biology, Adam Mickiewicz University, Poznań, Poland; \\ 2 Department of Biochemistry and Genetics Otago, University of Otago, Dunedin, New Zealand; \\ ${ }^{3}$ Department of Zoology, University of Otago, Dunedin, New Zealand; \\ ${ }^{4}$ Laboratory of Fish Genetics, Institute of Animal Physiology and Genetics, Academy of Sciences of the Czech Republic, Liběchov, Czech Republic; \\ ${ }^{5}$ Department of Biology and Ecology, Faculty of Science, University of Ostrava, Ostrava, Czech Republic
}

\begin{abstract}
A decrease in biodiversity and density of terrestrial organisms with increasing altitude and latitude is a well-known ecogeographical pattern. However, studies of these trends are often taxonomically-biased toward well-known organisms and especially those with relatively large bodies, and environmental variability at the local scale may perturb these general effects. Here, we focus on understudied organisms-soil invertebrates-in Antarctic deserts, which are among the driest and coldest places on Earth. We sampled two remote Antarctic sites in the Darwin Glacier area and established an altitudinal gradient running from 210 to $836 \mathrm{~m}$ a.s.l. We measured soil geochemistry and organic matter content and linked these parameters with the presence of soil invertebrates. We found three general outcomes, two of which are consistent with general assumptions: (a) the hostile climatic condition of the Darwin Glacier region supports an extremely low diversity of soil metazoans represented by a single nematode species-Scottnema lindsayae; (b) soil geochemistry is the main factor influencing distribution of nematodes at the local scale. Contrary to our expectations, a positive correlation was found between nematode density and altitude. This last observation could be explained by an additional effect of soil moisture as we found this increased with altitude and may be caused by orographic clouds, which are present in this region. To the best of our knowledge such effects have been described in tropical and temperate regions. Potential effect of orographic clouds on soil properties in polar deserts may be a fruitful area of ecological research on soil fauna.
\end{abstract}

\section{Keywords}

Altitudinal gradient; Antarctica; ecosystem variability; orographic clouds; Darwin Glacier; soil moisture

\section{Correspondence}

Karel Janko, Laboratory of Fish Genetics, Institute of Animal Physiology and Genetics, Academy of Sciences of the Czech Republic, Rumburská 89, 27721 Liběchov, Czech Republic. E-mail janko@iapg.cas.cz

\section{Abbreviations}

ASTM: American Society for Testing and Materials; GLM: generalized linear model; GLM.nb: GLM model with a negative binomial distribution; LOI: loss on ignition (estimation of organic matter)

\section{Introduction}

Ice-free areas in Victoria Land represent ca. 2\% of Antarctica's ice-free land. They are characterized by both low temperatures and precipitation, high sublimation rates, nutrient-poor soils and the presence of only a few multicellular species such as lichens, mosses and soil microfauna (e.g., Fountain et al. 1999; Doran et al. 2002; Porazińska et al. 2002a, b; Poage et al. 2008; Adlam et al. 2010). In these extreme ecosystems, moisture and organic matter availability are low, while salinity is relatively high in the thin top layer of soil that thaws during the summer, known as the "active soil layer"
(Courtright et al. 2001; Adlam et al. 2010). Although microbial communities are present in almost all soils (e.g., Cary et al. 2010), there are no vascular plants or vertebrates in this region (Horowitz et al. 1972), the densities and diversity of photoautotrophic organisms are low (Barrett et al. 2008), and the biota of these areas are severely restricted in distribution by extreme conditions and low productivity.

The simplicity of Antarctic dry valley ecosystems is an advantage for examining the influence of soil factors on the diversity of life as well as developing models to predict the potential impacts of climate change (Colesie et al. 2014; Andriuzzi et al. 2018). The best-investigated 
Antarctic deserts are the McMurdo Dry Valleys, where a long-term ecological research programme was established for studies on the variability of life and climatic and geochemical processes in a pristine, extreme ecosystem (e.g., Powers, Freckman, Ho et al. 1995; Freckman \& Virginia 1998; Doran et al. 2010). Studies in other icefree Antarctic areas beyond the McMurdo Dry Valleys are scarce (Ruprecht et al. 2010; Colesie et al. 2013; Colesie et al. 2014). In general, very little is known of Antarctic regional biogeography or of the diversity of these habitats (Adams et al. 2006; Convey et al. 2014; Velasco-Castrillón et al. 2014; Czechowski et al. 2016; Chown et al. 2017).

One such remote and poorly studied area is the Darwin Mountains region, one of the driest and coldest ecosystems in the world (Colesie et al. 2014). Extremely low water availability in the Darwin Mountains area is driven by very low precipitation and the largest sublimation rates in the Ross Sea region, coupled with low atmospheric water vapour pressure and a high water vapour pressure deficit (Bromwich \& Guo 2004). Limited access to remote field areas such as the Darwin Glacier region makes biological and physical characterization of such areas difficult.

There are few studies of the limno-terrestrial biology of the Darwin Glaciers region (Ruprecht et al. 2009; Webster-Brown et al. 2010; Colesie et al. 2013; Colesie et al. 2014), and no paper devoted to the Darwin Glacier region has focused exclusively and specifically on soil fauna. Filling this knowledge gap is important for understanding these unusual ecosystems, given the influence of soil fauna on nutrient cycling, mineralization and decomposition processes as they feed on primary organisms (Procter 1990). In fact, the Antarctic soil fauna has generally been understudied and most research effort has so far concentrated on easily accessible areas near research bases, particularly on the Antarctic Peninsula (e.g., Convey 2011; Chown et al. 2017).

Contemporary studies show that soil properties like moisture and conductivity in arid ecosystems are crucial for understanding the patterns of Antarctic biodiversity (Powers, Freckman, Ho et al. 1995; Powers, Freckman \& Virginia 1994, 1995; Porazińska et al. 2002a, b; Courtright et al. 2001; Nkem et al. 2006; Poage et al. 2008). In addition, the effect of altitude in such cold places may be even more crucial than at lower latitudes (Adams et al. 2006). The assumption of a mostly linear relationship between altitude and temperature led to the consideration of such gradients as useful proxies for predicting the effects of climate change on organisms (Iglesias Briones et al. 1997; Hodkinson 2005; Zawierucha et al. 2015; Andriuzzi et al. 2018). These assumptions may oversimplify these relationships, as the effects of latitude or altitude may be less significant than other local factors (Colesie et al. 2014). For example, temporary warming after cooling periods in the Ross Sea region may influence soil fauna as warmer years tend to be wetter (Andriuzzi et al. 2018).

Antarctic terrestrial invertebrate communities are likely to respond to climate changes both directly and indirectly. They are predictors of changes of microbial assemblage diversity and activity and the development of changes in Antarctic plant communities (Nielsen \& Wall 2013). Despite the fact that these regions are expected to have the most visible response to changing temperatures, studies on altitudinal gradients have rarely been conducted in either Antarctic deserts (Powers, Freckman \& Virginia 1995; Powers et al. 1998; Courtright et al. 2001; Porazińska et al. 2002b; Adlam et al. 2010; Andriuzzi et al. 2018) or in Antarctica as a whole (e.g., Gremmen et al. 2007).

A reasonably complete understanding of global biodiversity is crucial for studying both the evolution and ecology of these ecosystems and to provide answers as to how global-scale changes will affect them, especially those in fragile polar areas (Convey 2011; Nielsen \& Wall 2013). With so few studies published, there are many remote inland ice-free areas that have yet to be sampled and provide data for models of Antarctic climate change.

The main aims of our study were (a) a comparison of fauna in two regions (Diamond Hill and Bartrum Basin) that differ in altitude, topography and age of recent glaciation in the remote Darwin Glacier area and (b) to survey changes of soil fauna over altitudinal gradients on the slopes of Diamond Hill. In this study we identified prominent abiotic factors influencing the density of soil nematodes. We also investigated the possibility that humidity derived from orographic clouds may have a significant impact on polar soil biota.

\section{Material and methods}

\section{Study area}

We conducted our studies at two areas in the Darwin Glacier region $\left(79.88^{\circ} \mathrm{S} 159.00^{\circ} \mathrm{E}\right)$ : at Diamond Hill at the outlet of the glacier; and the Bartrum Basin, approximately $20 \mathrm{~km}$ to the west. This area, part of the Brown Hills, constitutes desert isolated by glaciers from mountain ranges and the sea (Fig. 1). Diamond Hill is located at the eastern edge of the Transantarctic Mountains, close to the Ross Ice Shelf and the north side of the outlet of the Darwin Glacier. It is dominated by outcrops of granite, granodiorite and high-grade metamorphic rocks (Carosi et al. 2007). Further inland, the Beacon Sandstones (Devonian-Triassic) are intruded by sills and dikes of 
Lower Jurassic tholeiitic dolerite (Elliot \& Fleming 2004). Cosmogenic exposure ages of exposed rocks in this region range from 1000 to 1 million years, and rocks at the Diamond Hill site are estimated to have been exposed, presumably by ice sheet retreat, for about 400000 years (Storey et al. 2010). The climate of Diamond Hill is characterized by higher air humidity and precipitation that supports a modest diversity and abundance of lichens somewhat greater than the Bartrum Basin (Ruprecht et al. 2010). Nevertheless, the few available studies of limno-terrestrial biology of the Darwin Glaciers region

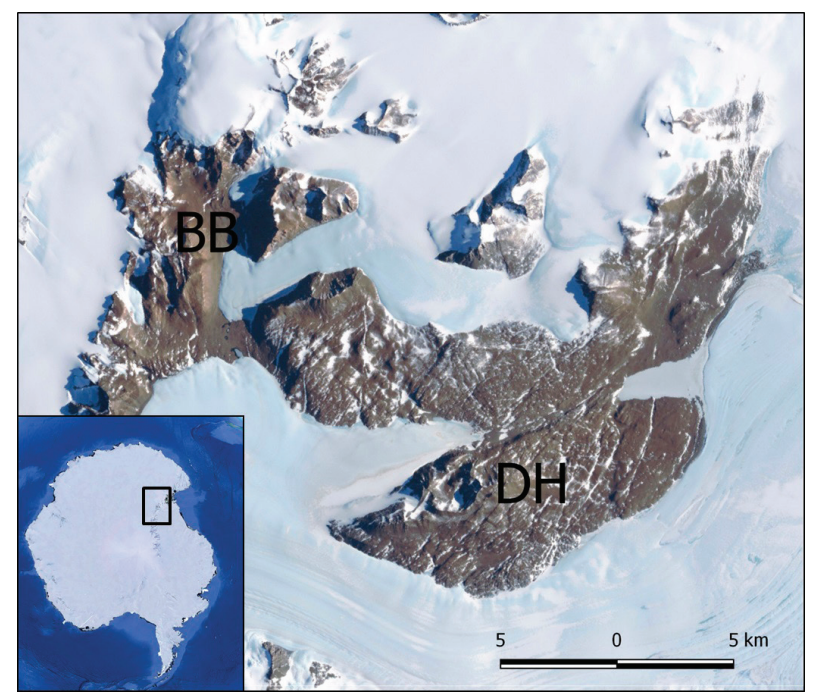

Fig. 1 The study area in Antarctica (insert), showing the locations of Bartrum Basin (BB) and Diamond Hill (DH).
(Ruprecht et al. 2009; Webster-Brown et al. 2010; Magalhăes et al. 2012; Colesie et al. 2013; Colesie et al. 2014) show low community diversity compared to other polar regions including the Dry Valleys. Webster-Brown et al. (2010) showed that benthic microbial mats in this area are thin and poorly developed, dominated by oscillatoriacean cyanobacteria. Nitrogen-fixing genera were generally absent, and diatoms were rare (Webster et al. 2010). Colesie et al. (2014) conducted the most comprehensive studies in this area as part of a broad survey of the Ross Sea coastline focusing on lichens, bryophytes and arthropods (springtails and mites). The Diamond Hill area of the Darwin Glacier yielded nine species of lichens, one bryophyte and only one invertebrate species, a mite (Colesie et al. 2014).

General climatic and biological data for Bartrum Basin are scarce. Bartrum Basin is located in the north-west of the Brown Hills and is apparently very dry with very little exposure to sunlight as it lies to the south and in the shade (for much of the year) of the Bowling Green Plateau. The dominant rock types are dolerite and granite (Ruprecht et al. 2010), but the geomorphologic history of Bartrum Basin is not well known and may contain the same elements as Diamond Hill.

\section{Sampling}

In January and February of 2009, a field survey and sampling in the Darwin Glacier area (Fig. 1) were carried out in order to investigate diversity and densities of soil fauna. Samples were collected from specific areas in the Bartrum Basin and at Diamond Hill (Fig. 2a, b). Fourteen samples

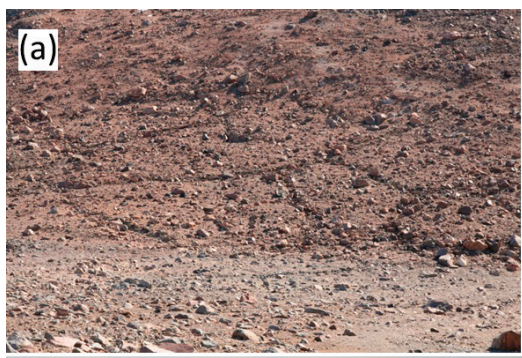

(c)

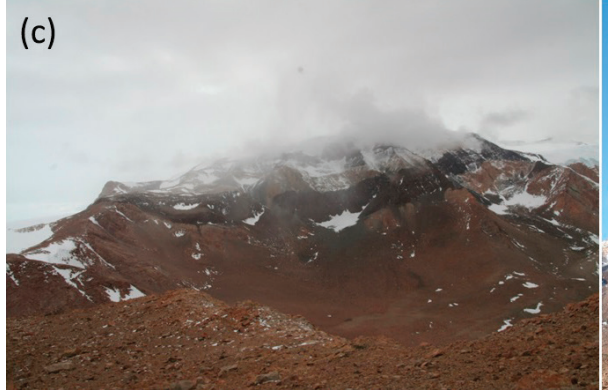

(b)

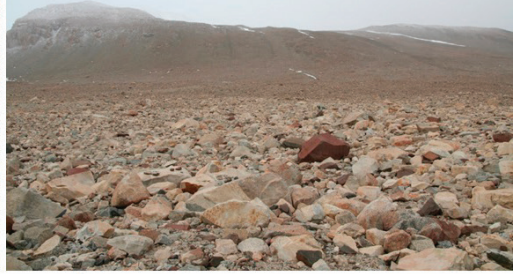

(d)

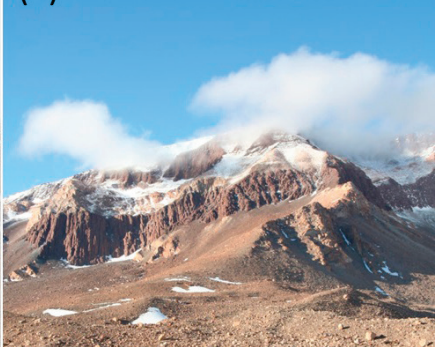

Fig. 2 (a) Soil in Diamond Hill; (b) stones in Bartrum Basin; (c, d) orographic clouds in the Darwin Glacier region. 
(each comprising two subsamples) were collected from Bartrum Basin in two altitudinal intervals ranging from 606 to 682 m. a.s.l. and from 969 to 1202 m a.s.l. Big rocks, a lack of typical soil/gravel layer and rock walls made it difficult to sample elevations spanning ca. 700-900 m a.s.l (Fig. 2b). Seventeen samples (11 consisting of two subsamples) were collected on Diamond Hill in an altitudinal gradient running from 210 to $836 \mathrm{~m}$ a.s.l. Samples were collected at ca. 50-140 m altitude intervals depending on the conditions. Samples were collected only in sites with limited stones and rock cover and where some kind of soil was present (Fig. 2a). This allowed for effective comparison of sites. Supplementary Table S1 provides the dry weights and associated geographic coordinates and altitudes for each sample.

The samples of about $500 \mathrm{~g}$ were collected from the upper $0-10 \mathrm{~cm}$ layer of soil using a sterile scoop, then placed in a sterile polyethylene bag and mixed thoroughly. Subsamples at each site were typically collected within $50 \mathrm{~m}$ of each other. Stones larger than $5 \mathrm{~cm}$ in diameter were excluded from the samples. All samples were maintained in the shade at ambient sub-zero temperatures in the field within chilly bins to minimize temperature variations. Sample were cooled to $-20^{\circ} \mathrm{C}$ at Scott Base and transported frozen to New Zealand, where they were stored at $-20^{\circ} \mathrm{C}$. Each bin weighed about $40 \mathrm{~kg}$ and responded slowly to changes in ambient temperature (less than $0.5^{\circ} \mathrm{C}$ per hour assessed by temperature monitors within the bin). Analysis was done as soon as possible but no later than three months after sampling.

\section{Nematode extraction}

Nematodes were extracted by a modified Baermann technique (Hooper et al. 2005). A 100 g portion of soil from each sample was thawed, placed on a sieve lined with two layers of tissue paper and immersed in water in a large glass Petri dish. The nematodes were recovered in the water in the Petri dish after 24 hr. The nematodes were collected by centrifugation, after which they were identified and counted under a microscope (Wharton et al. 2017). Nematodes were identified using the species descriptions by Timm (1971). This approach also yields rotifers and tardigrades from similar samples at Ross Island, suggesting that their absence in our samples reflects an absence from the environment in 2009.

\section{Geochemical analysis}

We measured basic geochemical parameters of the sampled soils. Soil moisture was determined gravimetrically from a $10 \mathrm{~g}$ subsample dried in an oven for $24 \mathrm{hr}$ at $100^{\circ} \mathrm{C}$. Organic carbon content was assessed by the combustion method: after dry weight assessment, the same soil sample was combusted at $500^{\circ} \mathrm{C}$ for $8 \mathrm{hr}$ and reweighed. Soil pH and conductivity (a proxy for salinity) were measured on a slurry made from a 1:2 (w/v) solution of the $<2 \mathrm{~mm}$ soil in ASTM Type 1 (mQ) water (7 $\mathrm{g}$ soil to $14 \mathrm{ml} \mathrm{mQ}$ according to standard approach [Barrett et al. 2002; Barrett et al. 2008]) to enable comparable models to be generated (Poage et al. 2008).

\section{Data analysis}

To identify the environmental factors underlying the distribution of nematodes, we performed a series of generalized linear models and zero-inflated models. Because the nematode count data were significantly over dispersed, we did not use a GLM with a Poisson family of error distribution. Instead, we used models with a negative binomial distribution (GLM.nb). Because we observed many sites with zero nematode abundance, we also employed zero-inflated models, which consider separately the processes determining presence or absence of nematodes at any site from the processes that affect the counts of nematodes at only those sites where nematodes were present.

Initially, all models were applied to nematode data, with a single environmental parameter analysed at a time. Subsequently, we also used the forward selection procedure to select all environmental variables that significantly explained the nematode distribution. The forward selection adds the variables with decreasing explanatory power in a stepwise manner until the more complex model does not significantly improve the fit to the data. The significance of the correlation was assessed by a likelihood ratio test by comparing the log likelihood of a given model to that of the null model (assuming no dependence of observed nematode abundances with soil parameters). The forward model selection was continued starting from the null model, and we considered the best model as the one that significantly increased the log Likelihood score compared to its nested and simpler model. The significance of each model as compared to the simpler nested model was tested with the ANOVA. GLM function using 0.05 as the cut-off value and with the appropriate type of test for the given GLM family. All these calculations were performed in the $\mathrm{R}$ software (R Development Core Team 2008).

Initially, all models were applied to combined data from both Bartrum Basin and Diamond Hill, but because the two areas largely differed in both physico-chemical properties and in nematode abundance (there was only one site with nematode occurrence within the Bartrum Basin), we also analysed the Diamond Hill region separately. 
Finally, to avoid the effect of spatial autocorrelation of sampling replicates taken at the same sites, we also repeated the same procedures with averaged data for each sampling site. Nematode averaged abundances were rounded to the nearest integer to fit the assumptions of the GLM.nb.

\section{Results}

\section{Fauna}

In soil samples we found only one species of nematode: Scottnema lindsayae (Timm, 1971). No other soil microfauna were found in these samples. At a first glance, there were clear differences between the two regions. Bartrum Basin soils were characterized by generally high soil conductivity (Fig. 3), and nematodes were found in only one sample (comprising two subsamples) with density of 38 per $100 \mathrm{~g}$. By contrast, the soil conductivity (a proxy for salinity) was relatively low in the Diamond Hill region (Fig. 3), with most sites containing S. lindsayae: 70.6\% of samples from Diamond Hill contained an average of 12.93 nematodes per $100 \mathrm{~g}$. The highest density of nematodes was recorded at $789 \mathrm{~m}$ a.s.l., with 113 per $100 \mathrm{~g}$.

\section{Influence of soil parameters on nematode distribution and abundance}

Using the entire data set over both regions, the GLM. nb indicated a highly significant effect of conductivity $(z=-3.171$, $p=0.0015$ ), where high conductance values (i.e., $>1000$ $\mu S)$ clearly correlated with the absence of $S$. lindsayae at

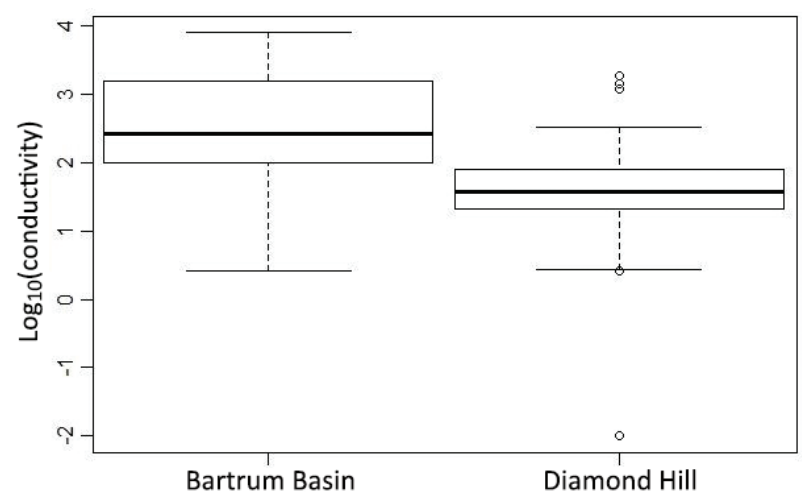

Fig. 3 Differences in conductivity between Bartrum Basin and Diamond Hill. In each boxplot, the median is indicated by a horizontal line; the box encompasses the second and third data quartiles, while whiskers encompass the data within the interval given by the lowest value of the 1.5 interquartile range of the first quartile and the highest value of the 1.5 interquartile range of the third quartile. Outliers are denoted by empty circles. most sites in the Bartrum Basin and some sites in the Diamond Hill regions. Therefore, all other analyses were performed with the zero-inflated models, where conductivity was used as an explanatory variable in the zero-inflation binomial component with the logit link function, while all other variables were used as predictor in the count component of the model with negative binomial error distribution with the log link. We initially applied the zero-inflated model with each predictor variable considered separately for the total data set as well as the data from only Diamond Hill. In both cases, we found significant effects of only two factors, specifically, altitude (total data set: $z=3.622$, $p=0.0003$; Diamond Hill data set: $z=3.779, p=0.00016$ ) and relative soil moisture (total data set: $z=2.094$, $p=0.036$; Diamond Hill data set: $z=1.913, p=0.055$ ).

When we applied the forward selection of zero-inflated models to the total data set, we identified altitude as the only significant variable, as the addition of any other variable did not improve the model fit. By contrast, when applying the forward selection to the Diamond Hill data only, we identified three significant variables: altitude, organic matter and $\mathrm{pH}$, which all showed a positive correlation with nematode abundance.

To avoid the effect of spatial autocorrelation of sampling replicates taken at the same sites, we also repeated the same procedures with averaged data for each sampling site (nematode averaged abundances were rounded to the nearest integer to fit the assumptions of the GLM.nb). When applying the zero-inflated models with individual predictor variables to the averaged data from both sites, we found only a significant effect of altitude $(z=3.379, p=0.000726)$, whereas analysis of the Diamond Hill sites showed significant effects of two parameters, altitude $(z=3.322$, $p=0.000895)$ and soil moisture $(z=1.966, p=0.049)$.

In summary, we stress that in most data sets the soil moisture appeared significantly positively correlated with nematode abundances when used as the only predictor variable, but its effect was not significant when performing the forward selection procedure. However, soil moisture was significantly positively correlated with altitude (linear model $t=2.484, p=0.0201$, Fig. 4a), which may explain this observation. There was no significant relation between soil conductivity and altitude and soil conductivity and moisture (Fig. 4b, c).

Overall, soil conductivity was the significant parameter driving the distribution of nematodes. The Bartrum Basin contained soils with very high conductivity, and nematodes generally were absent in this region. Taking the detrimental effect of conductivity into account using the zero-inflated models, we found that nematode density positively correlated with altitude (and soil moisture, which was correlated with altitude), organic carbon (LOI) and $\mathrm{pH}$ (Fig. 5). 

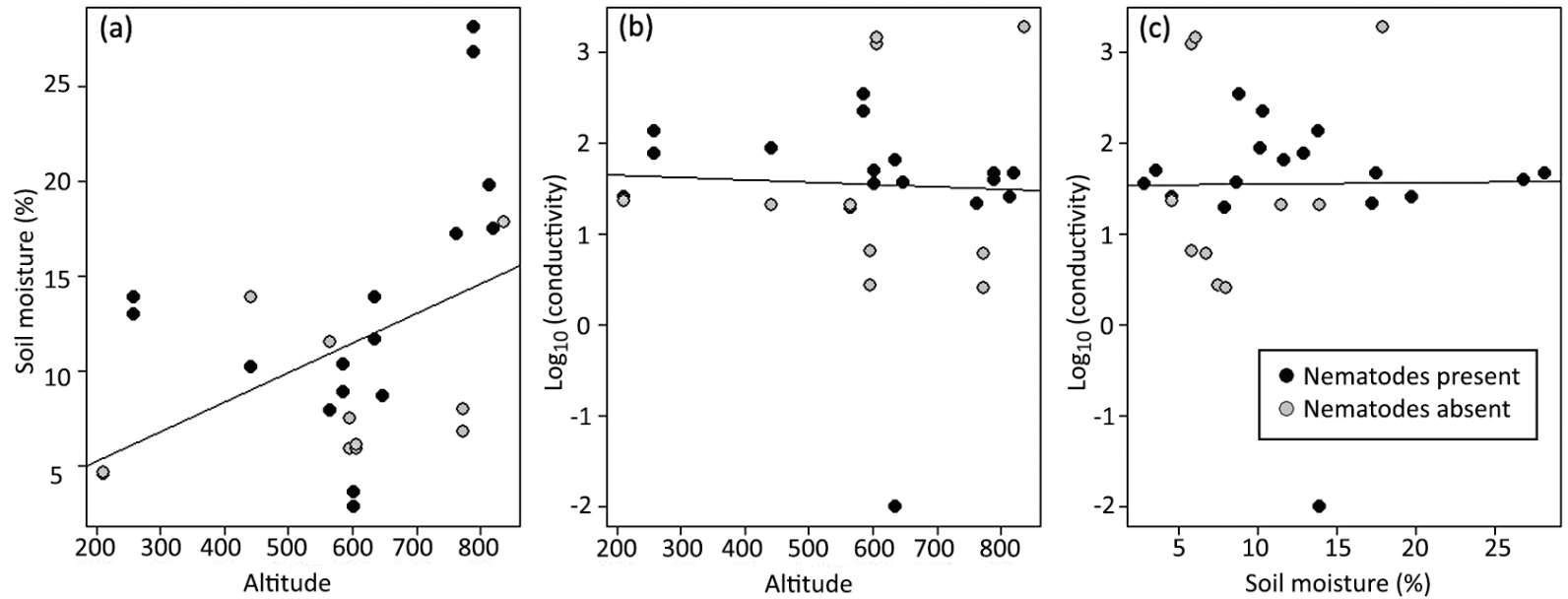

Fig. 4 The relation of (a) soil moisture and altitude, (b) conductivity and altitude and (c) conductivity and soil moisture on Diamond Hill sites.
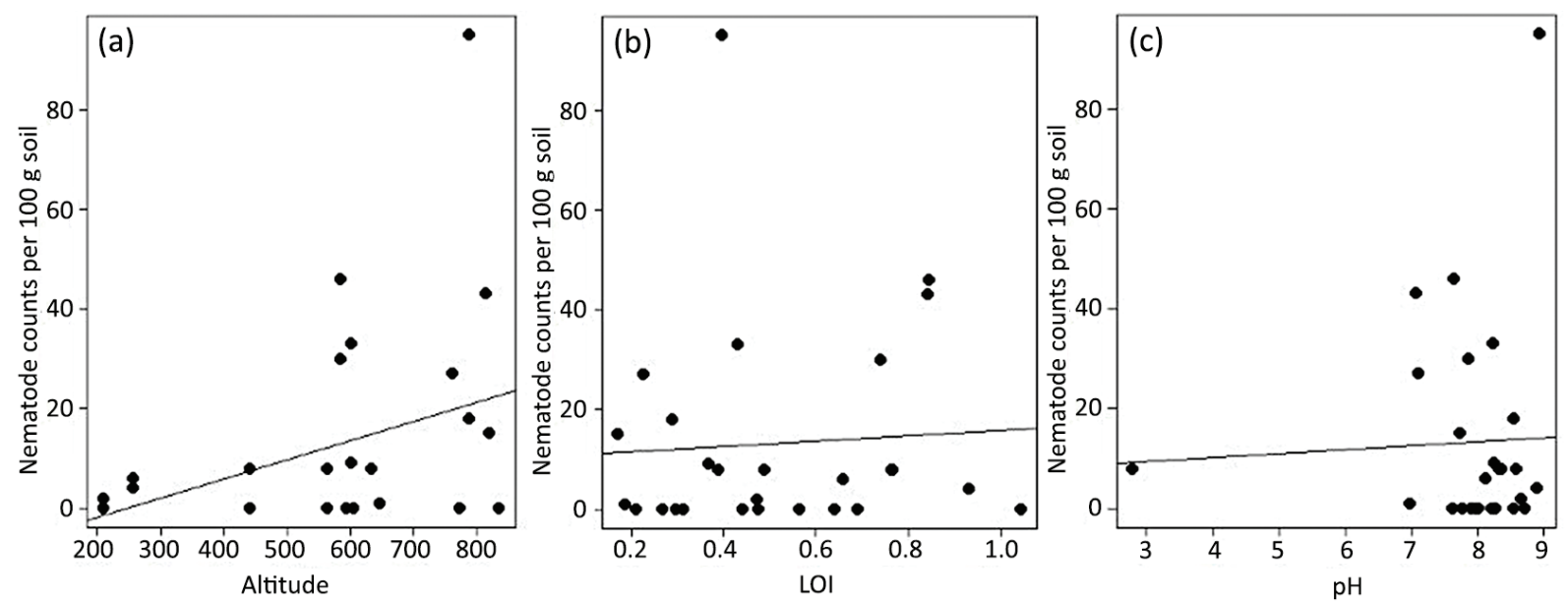

Fig. 5 The relation of nematode densities to (a) altitude, (b) organic matter content (LOI) and (c) pH.

\section{Discussion}

Soil ecosystems of the high Antarctic have previously been documented as extremely poor in biodiversity in comparison with other parts of the world, including deserts-some areas are dominated by rotifers and tardigrades as the only metazoans (Convey $\&$ McInnes 2005). As to nematodes, which form one of the most dominant and speciose groups in all other continents, their diversity is as low as three morphospecies throughout the high Antarctic ice-free areas (Freckman \& Virginia 1997). In this study we investigated desert soils from one of the harshest climates on Earth-the Darwin Glacier region-and found evidence for one of the most impoverished regions of metazoan soil diversity, with only a single species of nematode $-S$. lindsayae-present in this region. This species is the "southernmost worm" (Adams et al. 2007) and may form a dominant component of nematode assemblages in the polar deserts of Victoria Land (e.g., Freckman \& Virginia 1997; Porazińska et al. 2002b; Powers, Freckman \& Virginia et al. 1995; Adams et al. 2014). In Victoria Land, S. lindsayae occurs most commonly in dry, bare, sandy or rocky substrates, where it is often the apex consumer (e.g., Powers, Freckman \& Virginia et al. 1995; Adams et al. 2014). However, the material in our study was collected in 2009 and according to Andriuzzi et al. (2018) significant climatic shifts took place in the McMurdo Dry Valleys during this time. We can therefore not exclude the possibility that currently there are more representatives of microfauna in the Darwin Glacier region.

Our study represents the first record of this species in the Darwin Glacier region, with the unique finding 
of this species as the single representative of the entire metazoan community in our samples. We also discovered some associations between its occurrence and specific soil characteristics that warrant further discussion, including the unexpected relationship of altitude to soil moisture.

\section{Soil conductivity}

Our results showed that conductivity has the strongest negative correlation with nematode counts in the area of Darwin Glacier. The Bartrum Basin was characterized by soil conductivity much higher than at Diamond Hill and was also almost free of nematodes. We found $S$. lindsayae at a single site where the conductivity was lower than elsewhere in the Bartrum Basin region.

Electrical conductivity was previously suggested as a factor influencing the mortality of nematodes in Antarctic soils (Powers et al. 1998). Poage et al. (2008) established a statistical basis for understanding invertebrate distribution over the entire Dry Valleys in Victoria Land. They suggested that salinity, which correlates with soil conductivity, plays a primary role in determining the nematode habitat suitability (Poage et al. 2008). They found that soil salinity has a significant influence on the distribution of S. lindsayae in Antarctic deserts (Freckman \& Virginia 1997; Porazińska et al. 2002b; Poage et al. 2008), and this nematode is mostly found predominantly in soils with

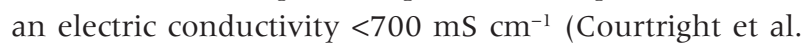
2001; Poage et al. 2008). Our studies agreed with these previous findings and support the proposal that soil conductivity in dry valleys is an important driver of the distribution of soil nematodes, and this in turn may decisively affect soil communities even on a small geographic scale.

\section{Altitude and moisture}

We found a positive correlation between S. lindsayae abundance and altitude or soil humidity, or both, at Diamond Hill. In general, the altitudinal gradients on mountain slopes help to define the biological patterns and processes that emerge as key factors for species richness, abundance and distribution (e.g., Iglesias Briones et al. 1997; Hodkinson 2005). These gradients are especially important in fragile polar ecosystems sensitive to environmental changes (e.g., Zawierucha et al. 2015). A significant relationship between invertebrate communities and elevation has been documented in a number of surveys (e.g., Nelson 1975; Dastych 1985, 1988; Wolda 1987; Porazińska et al. 2002b; Porazińska et al. 2004; Guil et al. 2009; Zawierucha et al. 2015; Andriuzzi et al. 2018), but there is no consensus as to which variables relating to elevation (e.g., temperature, moisture, UV, vegetation or others) are causally responsible for shaping invertebrate diversity, distribution and abundance. Many of these studies provide conflicting results, reporting a positive (e.g., Wood 1974; Nelson 1975; Dastych 1988; Porazińska et al. 2002b; Sadaka \& Ponge 2003; Devetter et al. 2017), a negative (e.g., Dastych 1985; Porazińska et al. 2002b; Stebaeva 2003; Wang et al. 2009) or no relationship (e.g., Kathman \& Cross 1991; Powers et al. 1998; Zawierucha et al. 2015) between invertebrates and elevation. Similar inconsistencies with altitude were found in microbial communities. Kotas et al. (2017) showed that in the Arctic, microbial biomass increases with altitude, but it seems that such responses may be taxon dependent (Gremmen et al. 2007; Bryant et al. 2008).

Some previous studies showed that densities of S. lindsayae, the focal species of our study, increased along an altitudinal gradient in the Dry Valleys, but these data were collected along a shorter transect at lower elevations (83-392 m a.s.l.) (Porazińska et al. 2002b; Andriuzzi et al. 2018). In this work, changes of climatic variables weren't so discernible as in our study, which showed a positive correlation of nematode abundance with altitude along a much longer transect spanning from 210 to $836 \mathrm{~m}$ a.s.l. More importantly, our study suggested that S. lindsayae distribution is positively affected by soil moisture, either considered as a single factor or correlated with altitude. Our finding that $S$. lindsayae inhabits soil patches with a high moisture content at Diamond Hill was surprising given contemporary, albeit scarce, data on S. lindsayae biology. Although $S$. lindsayae was reported to tolerate a wide range of soil moistures, the studies of Porazińska et al. (2002b) and Treonis et al. (1999) reported a negative effect of soil moisture on $S$. lindsayae densities, suggesting that, contrary to our findings, this species prefers dry habitats and tends to avoid moister habitats such as snow-covered soil or the edge of streams.

Recent work by Andriuzzi et al. (2018) suggested a different pattern when they examined the effect of varying climatic conditions on S. lindsayae abundance. During warming periods they found a decline in $S$. lindsayae and an increased abundance and expanded distribution of other taxa. These shifts are likely to result from an enhanced ice melt. They also found that at low and midelevations, the presence of moisture was negatively correlated with S. lindsayae abundance (Andriuzzi et al. 2018).

Antagonistic interactions amongst soil nematodes in Antarctic valleys may explain varying densities as well as the distribution of species, including $S$. lindsayae (Shaw et al. 2018). All previous studies investigating the ecology of Antarctic soil nematodes have been conducted in ecosystems with few coexisting nematode species, where the negative correlation of $S$. lindsayae with moisture was probably caused by competitive displacement by other species that out-performed $S$. lindsayae in wetter 
conditions (Andriuzzi et al. 2018). In the absence of competing species, moisture might pose less of a disadvantage to $S$. lindsayae and account for our findings of an increased abundance of $S$. lindsayae in moister soils.

\section{Orographic clouds: potential source of water}

The discrepancies among different studies in terms of the effect of moisture on S. lindsayae abundance (positive or negative) may reflect inconsistent sampling schemes or a lack of climatic data from the investigated areas that may fail to reveal the true factors influencing different outcomes at various study sites. The best examples of the latter effect are demonstrated in deserts where isolated mountains or steep slopes intercept the clouds with a resulting formation of a fog zone. In the Atacama Desert, for example, this fog is the most important source of water for plants and the soil crust (Cáceres et al. 2007). At meso-climatic scales, such orographic clouds increase moisture and humidity on upper mountain slopes, with considerable effect on the local biota, which may locally deviate from general trends (Cereceda et al. 2002; Scholl et al. 2007; Cochrane 2011; Sawaske \& Freyberg 2015). For polar regions we found no studies linking the biodiversity, densities or biomass of biota to orographic clouds, although the relationship between humidity and biocrusts in the Antarctic is briefly discussed by Green \& Proctor (2016). In fact, the orographic clouds are not only typical for tropical mountain forests (Pounds et al. 1999) and deserts (Cáceres et al. 2007) but are also common in polar regions, including Victoria Land (Zibrodi \& Frezzotti 1996). We observed them several times in the Darwin Glacier region during our brief visit (Fig. 2c, d). Scott $\delta$ Lubin (2016) note the variable effect of orographic precipitation on parts of Ross Island, providing evidence that such regional variations in precipitation are possible. Nevertheless, although the positive effect of orographic clouds on soil biology has been neither studied nor demonstrated in polar regions, we hypothesize that this may be one explanation for our finding increasing densities of nematodes with altitude.

We note that the few other studies devoted to soil biology in Victoria Land do not fit our observations. Andriuzzi et al. (2018) found a negative effect of moisture on S. lindsayae. Porazińska et al. (2002b) reported decreasing soil moisture with altitude and Powers et al. (1998) found that electrical conductivity and $\mathrm{pH}$ increased and soil moisture, organic carbon and organic nitrogen decreased with distance (and elevation) from lakes in the McMurdo Valleys. Moreover, Gooseff et al. (2003) reported no relationship between dry and moist soil under snow packs and $S$. lindsayae, suggesting that densities of this species may be linked to changing osmotic potential and salinity (Adams et al. 2014). However, water is a limiting factor in our study area, and there may be a threshold effect providing sufficient water crucial for life.

\section{Other factors: carbon, $\mathrm{pH}$}

Apart from soil moisture and electrical conductivity, there are other variables correlated with diversity, densities and biomass of soil invertebrates, among which organic carbon is important (e.g., Moorhead et al. 2003). Although organic carbon content in our studies was positively correlated with the presence of $S$. lindsayae, the significance of this effect remains unclear in Antarctic ecosystems (Powers et al. 1998; Cortright et al. 2001; Porazińska et al. 2002a).

Poage et al. (2008) measured the pH of soils in the McMurdo Dry Valleys with values ranging from 7.87 to 9.63. We noted similar $\mathrm{pH}$ values for the Darwin Glacier region over the range 6.98-9.18 (and one subsample outlier of 2.79). Soil $\mathrm{pH}$ has been proposed as one of the predictors for the presence of active $S$. lindsayae in Antarctic desert ecosystems. Poage et al. (2008) showed that soil $\mathrm{pH}$ negatively correlates with $S$. lindsayae abundance and positively with mortality. These authors stressed that there was a strong negative logarithmic relationship between soil conductivity and $\mathrm{pH}$ that may reflect electrode-specific influences of dissolved salts on the measurement of pH (Poage et al. 2008). We did not separate nematodes into alive and dead groups, and hence the absence of a count of dead nematodes may mask any negative effect of $\mathrm{pH}$.

\section{Conclusion}

Local climatic regimes of the environment (e.g., rainfall, humidity, temperature) seem to be responsible for the development and maintenance of invertebrates at a small scale (e.g., Andrew et al. 2003; Guil et al. 2009; Chown \& Klok 2013; Convey et al. 2014; Zawierucha et al. 2019). However, the most important factors influencing densities of Antarctic soil fauna in deserts seems to be related to the soil geochemistry, and the differences at the meso-scale between the Bartrum Basin and Diamond Hill mirror this effect. Interactions between soil moisture and salinity are complex and create various osmotic conditions for soil invertebrates (Adams et al. 2014), suggesting we need to know more to understand even simple terrestrial ecosystems such as Antarctic deserts. The role of orographic clouds as a source of water for mountain peaks in polar deserts may explain differences in the spatial distribution of soil biota over altitudinal gradients and should be taken into account in future studies. 
Organismal response to soil parameters not only reflects its intrinsic requirements but also its interactions with other organisms. This is reflected by the differences between our study, which investigated an extreme ecosystem with a single metazoan species, S. lindsayae, and demonstrated a positive effect of soil moisture on its abundance, and studies by Porazińska et al. (2002b) and Treonis et al. (1999), who reported adverse effects in more complex ecosystems with more interacting species, as well as by Andriuzzi et al. (2018), who found a relationship between decreasing densities of S. lindsayae along with expanded distribution of other soil taxa.

Nematodes play an important role in carbon cycling in Antarctic soils, and changes in nematode distribution are therefore likely to be linked with changes in ecosystem functioning and may become especially visible during global warming (Barrett et al. 2008). If climate change acts as expected and increases global sea surface temperatures, the cascading effects related, but not limited, to shrinking glaciers, changing precipitation patterns, wind circulation and orographic clouds may have an impact not only on alpine biota (Cochrane 2011 ; Vaughan et al. 2013 ) but also on organisms inhabiting mountains peaks in remote polar regions.

\section{Acknowledgements}

The authors thank Antarctica New Zealand for their support of K066 both in the field and at Scott Base, and Tim Hawes and Roman Türk for invaluable field assistance. The authors would like to thank Michał Bogdziewicz for his comments on statistics and Kamil Laska and Dan Nyvlt for comments on climatic and geological aspects of the paper. Last but not least, the authors would like to thank Professor Marek Lewandowski and Dr Adam Nawrot (Institute of Geophysics, Polish Academy of Sciences) for comments on the meteorology, geomorphological features and history of Victoria Land.

\section{Disclosure statement}

No potential conflict of interest was reported by the authors.

\section{Funding}

Studies were supported by institutional support RVO 67985904 and by the project Excellence CZ.02.1.01/0.0/ 0.0/15_003/0000460 OP RDE to KJ and KZ.

\section{References}

Adams B.J., Bardgett R.D., Ayres E., Wall D.H., Aislabie J., Bamforth S., Bargagli R., Cary C., Cavacini P., Connell L., Convey P., Fell J.W., Frati F., Hogg I.D., Newsham K.K., O'Donnell A., Russell N., Seppelt R.D. \& Stevens M.I. 2006. Diversity and distribution of Victoria Land biota. Soil Biology and Biochemistry 38, 3003-3018, http://dx.doi. org/10.1016/j.soilbio.2006.04.030.

Adams B.J., Wall D.H., Gozel U., Dillman A.R., Chaston J.M. \& Hogg I.D. 2007. The southernmost worm, Scottnema lindsayae (Nematoda): diversity, dispersal and ecological stability. Polar Biology 30, 809-815, http://dx.doi.org/10.1007/ s00300-006-0241-3.

Adams B.J., Wall D.H., Virginia R.A., Broos E. \& Knox M.A. 2014. Ecological biogeography of the terrestrial nematodes of Victoria Land, Antarctica. ZooKeys 419, 29-71, http://dx. doi.org/10.3897/zookeys.419.7180.

Adlam H.S., Balks M.R., Seybold C.A. \& Campbell D.I. 2010. Temporal and spatial variation in active layer depth in the McMurdo Sound Region, Antarctica. Antarctic Science 22, 45-52, http://dx.doi.org/10.1017/S0954102009990460.

Andrew R., Rodgerson L. \& Dunlop M. 2003. Variation in invertebrate-bryophyte community structure at different spatial scales along altitudinal gradients. Journal of Biogeography 30, 731-746, http://dx.doi.org/10.1046/j. 1365-2699.2003.00849.x.

Andriuzzi W.F., Adams B.J., Barrett J.E., Virginia R.A. \& Wall D.H. 2018. Observed trends of soil fauna in the Antarctic Dry Valleys: early signs of shifts predicted under climate change. Ecology 99, 312-321, http://dx.doi.org/10.1002/ ecy. 2090.

Barrett J.E., Johnson D.W. \& Burke I.C. 2002. Abiotic nitrogen uptake in semiarid grassland soils of the U.S. Great Plains. Soil Science Society of America Journal 66, 979-987.

Barrett J.E., Virginia R.A., Wall D.H. \& Adams B.J. 2008. Decline in a dominant invertebrate species contributes to altered carbon cycling in a low-diversity soil ecosystem. Global Change Biology 14, 1734-1744, http://dx.doi. org/10.1111/j.1365-2486.2008.01611.x.

Bromwich D.H. \& Guo Z. 2004. Modelled Antarctic precipitation. Part I: spatial and temporal variability. Journal of Climate 17, 427-447, http://dx.doi.org/10.1175/ 1520-0442(2004)017<0427:MAPPIS>2.0.CO;2.

Bryant J.A., Lamanna C., Morlon H., Kerkhoff A.J., Enquist B.J. \& Green J.L. 2008. Microbes on mountainsides: contrasting elevational patterns of bacterial and plant diversity. Proceedings of the National Academy of Sciences of the United States of America 12, 11505-11511, http://dx.doi. org/10.1073/pnas.0801920105.

Cáceres L., Gómez-Silva B., Garró X., Rodrìguez V., Monardes V. \& McKay CH.P. 2007. Relative humidity patterns and fog water precipitation in the Atacama Desert and biological implications. Journal of Geophysical Research-Biogeosciences 112, g04s 14, http://dx.doi.org/10.1029/2006JG000344.

Carosi R., Giacomini F., Talarico F. \& Stump E. 2007. Geology of the Byrd Glacier Discontinuity (Ross Orogen): new survey data 
from the Britannia Range, Antarctica. Open-File Report 20071047-SRP-030. Reston, VA: US Geological Survey. http:// dx.doi.org/10.3133/ofr20071047SRP030.

Cary C.S., Mcdonald I.R., Barrett J.E. \& Cowan D.A. 2010. On the rocks: the microbiology of Antarctic Dry Valley soils. Nature Reviews 8, 129-138, http://dx.doi.org/10.1038/ nrmicro2281.

Cereceda P.P., Osses H., Larrain M., Faras M., Lagos, R.P. \& Schemenauer R.S. 2002. Advective, orographic and radiation fog in the Tarapaca region, Chile. Atmospheric Research 64, 261271, http://dx.doi.org/10.1016/S0169-8095(02)00097-2.

Chown S.L., Brooks C.M., Terauds A., Le Bohec C., van Klaveren-Impagliazzo C., Whittington J.D., Butchart S.H.M., Coetzee B.W.T., Collen B., Convey P., Gaston K.J., Gilbert N., Gill M., Hoft R., Johnston S., Kennicutt M.C., Kriesell H.J., Le Maho Y., Lynch H.J., Palomares M., PuigMarco R., Stoett P. \& McGeoch M.A. 2017. Antarctica and the strategic plan for biodiversity. PLoS Biology 15, e2001656, http://dx.doi.org/10.1371/journal.pbio.2001656.

Chown S.L. \& Klok J.C. 2013. Altitudinal body size clines: latitudinal effects associated with changing seasonality. Ecography 26, 445-455, http://dx.doi.org/10.1034/j.16000587.2003.03479.x.

Cochrane M. 2011. The fate of alpine species in the face of climate change: a biogeographic perspective. Macalester Reviews in Biogeography 2, article no. 1.

Colesie C., Gommeaux M., Green T.G.A. \& Büdel B. 2013. Biological soil crusts in continental Antarctica: Garwood Valley, southern Victoria Land, and Diamond Hill, Darwin Mountains region. Antarctic Science 26, 115-123, http://dx. doi.org/10.1017/S0954102013000291.

Colesie C., Green T.G.A., Türk R., Hogg I.D., Sancho L.G. \& Bödel B. 2014. Terrestrial biodiversity along the Ross Sea coastline, Antarctica: lack of a latitudinal gradient and potential limits of bioclimatic modeling. Polar Biology 37, 11971208, http://dx.doi.org/10.1007/s00300-014-1513-y.

Convey P. 2011 . Antarctic terrestrial biodiversity in a changing world. Polar Biology 34, 1629-1641, http://dx.doi.org/ 10.1007/s00300-011-1068-0.

Convey P., Chown S.L., Clarke A., Barnes D.K.A., Bokhorst S., Cummings V., Ducklow H.W., Frati F., Green T.G.A., Gordon S., Griffiths H.J., Howard-Williams C., Huiskes A.H.L., Laybourn-Parry J., Lyons W.B., McMinn A., Morley S.A., Peck L.S., Quesada A., Robinson S.A., Schiaparelli S. \& Wall D.H. 2014. The spatial structure of Antarctic biodiversity. Ecological Monographs 84, 203-244, http://dx.doi. org/10.1890/12-2216.1.

Convey P. \& McInnes S.J. 2005. Exceptional tardigradedominated ecosystems in Ellsworth Land, Antarctica. Ecology 86, 519-527, http://dx.doi.org/10.1890/04-0684.

Courtright E.M., Wall D.H. \& Virginia R.A. 2001. Determining habitat suitability for soil invertebrates in an extreme environment: the McMurdo Dry Valleys, Antarctica. Antarctic Science 13, 9-17.

Czechowski P., White D., Clarke L., McKay A., Cooper A. \& Stevens M.I.R. 2016. Age-related environmental gradients influence invertebrate distribution in the Prince Charles Mountains, East Antarctica. Royal Society Open
Science 3, article no. 160296, http://dx.doi.org/10.1098/ rsos. 160296.

Dastych H. 1985. West Spitsbergen Tardigrada. Acta Zoologica Cracviensia 28, 169-214.

Dastych H. 1988. The Tardigrada of Poland. Monografie FaunyPolski 16. Warsaw: Państwowe Wydawnictwo Naukowe.

Devetter M., Háněl L., Řeháková K. \& Doležal J. 2017. Diversity and feeding strategies of soil microfauna along elevation gradients in Himalayan cold deserts. PLoS One 12(11), e0187646, http://dx.doi.org/10.1371/journal.pone.0187646.

Doran P.T., Lyons W.B. \& McKnight D.M. 2010. Life in Antarctic deserts and other cold dry environments. Astrobiological analogs. Cambridge: Cambridge University Press. doi: http:// dx.doi.org/10.1017/CBO9780511712258.

Doran P.T., McKay C.P., Clow G.D., Dana G.L., Fountain A.G., Nylen T. \& Lyons W.B. 2002. Valley floor climate observations from the McMurdo Dry Valleys, Antarctica, 1986-2000. Journal of Geophysical Research-Atmospheres 107, article no. 4772, http://dx.doi.org/10.1029/2001JD002045.

Elliot D. \& Fleming T. 2004. Occurrence and dispersal of magmas in the Jurassic Ferrar Large Igneous Province, Antarctica. GondwanaResearch 7, 223-237, http://dx.doi. org/10.1016/S1342-937X(05)70322-1.

Fountain A.F., Lyons W.B., Burkins M.B., Dana G.L., Doran P.T., Lewis K.J, McKnight D.M., Moorhead D.L., Parsons A.N., Priscu J.C., Wall D.H., Wharton R.A. Jr. \& Virginia R.A. 1999. Physical controls on the Taylor Valley ecosystem, Antarctica. BioScience 49, 961-971, http://dx.doi. org/10.2307/1313730.

Freckman D.W. \& Virginia R.A. 1997. Low diversity Antarctic soil nematode communities: distribution and response to disturbance. Ecology 78, 363-369.

Freckman D.W. \& Virginia R.A. 1998. Soil biodiversity and community structure in the McMurdo Dry Valleys, Antarctica. In J.C. Priscu (ed.): Ecosystem dynamics in a polar desert: the McMurdo Dry Valleys, Antarctica. Pp. 323-335. Washington, DC: American Geophysical Union. http://dx. doi.org/10.1029/AR072p0323

Gooseff M.N., Barrett J.E., Doran P.T., Fountain A.G., Lyons W.B., Parsons A.N., Porazińska D.L., Virginia R.A. \& Wall D.H. 2003. Snow-patch influence on soil biogeochemical processes and invertebrate distribution in the McMurdo Dry Valleys, Antarctica. Arctic Antarctic and Alpine Research 35, 91-99, http://dx.doi. org/10.1657/1523-0430(2003)035[0091:SPIOSB]2.0.CO;2.

Green T.G.A. \& Proctor M.C.F. 2016. Physiology of photosynthetic organisms within biological soil crusts: their adaptation, flexibility, and plasticity. In B. Weber et al. (eds.): Biological soil crusts: an organizing principle in drylands. Pp. 347-381. Dordrecht: Springer. http://dx.doi. org/10.1007/978-3-319-30214-0_18.

Gremmen N.J.M., Van DeVijver B., Frenot Y. \& Lebouvier M. 2007. Distribution of moss-inhabiting diatoms along an altitudinal gradient at sub-Antarctic Îles Kerguelen. Antarctic Science 19, 17-24, http://dx.doi.org/10.1017/ S0954102007000041.

Guil N., Hortal J., Sánchez-Moreno S. \& Machordom A. 2009. Effects of macro and micro-environmental factors on the 
species richness of terrestrial tardigrade assemblages in an Iberian mountain environment. Landscape Ecology 24, 375-390, http://dx.doi.org/10.1007/s10980-008-9312-x.

Hodkinson I.D. 2005. Terrestrial insects along elevation gradients: species and community responses to altitude. Biological Reviews 80, 489-513, http://dx.doi.org/10.1017/ S1464793105006767.

Hooper D.J., Hallman J. \& Subbotin S.A. 2005. Methods for extraction, processing and detection of plant and soil nematodes. In M. Luc et al. (eds.): Plant parasitic nematodes in subtropical and tropical agriculture. Pp. 53-86. Wallingford, UK: CABI Publishing. http://dx.doi. org/10.1079/9780851997278.0053.

Horowitz N.H., Cameron R.E. \& Hubbard J.S. 1972. Microbiology of Dry Valleys of Antarctica. Science 176, 242-245, http://dx.doi.org/10.1126/science.176.4032.242.

Iglesias Briones M.J., Trevor P. \& Piearce G. 1997. Effects of climate change on soil fauna; responses of enchytraeids, Diptera larvae and tardigrades in a transplant experiment. Applied Soil Ecology 6, 117-134, http://dx.doi.org/10.1016/ S0929-1393(97)00004-8.

Kathman R.D. \& Cross S.F. 1991. Ecological distribution of moss-dwelling tardigrades on Vancouver Island, British Columbia, Canada. Canadian Journal of Zoology 69, 122-129, http://dx.doi.org/10.1139/z91-018.

Kotas P., Šantrůčková H., Elster J. \& Kaštovská E. 2017. Soil microbial biomass, activity and community composition along altitudinal gradients in the High Arctic (Billefjorden, Svalbard). Biogeosciences 15, 1879-1894, http://dx.doi. org/10.5194/bg-15-1879-2018.

Magalhăes C., Stevens M.I., Cary S.C., Ball B.A., Storey B.C., Wall D.H., Türk R. \& Ruprecht U. 2012. At limits of life: multidisciplinary insights reveal environmental constraints in biotic diversity in continental Antarctica. PLoS One 7, e44578, http://dx.doi.org/10.1371/journal. pone. 0044578 .

Moorhead D.L., Barrett J.E., Virginia R.A., Wall D.H. \& Porazińska D. 2003. Organic matter and soil biota of upland wetlands in Taylor Valley, Antarctica. Polar Biology 26, 567-576, http://dx.doi.org/10.1007/s00300-003-0524-x.

Nelson D.R. 1975. Ecological distribution of tardigrades on Roan Mountain, Tennessee-north Carolina. Memorie Dell'Istituto Italiano di Idrobiologia 32, 225-276.

Nielsen U.N. \& Wall D.H. 2013. The future of soil invertebrate communities in polar regions: different climate change responses in the Arctic and Antarctic? Ecology Letters 16, 409-419, http://dx.doi.org/10.1111/ele.12058.

Nkem J.N., Virginia R.A., Barrett J.E., Wall D.H. \& Li G. 2006. Salt tolerance and survival thresholds for two species of Antarctic soil nematodes. Polar Biology 29, 643-651, http://dx.doi.org/10.1007/s00300-005-0101-6.

Poage M.A., Barrett J.E., Virginia R.A. \& Wall D.H. 2008. The influence of soil geochemistry on nematode distribution, McMurdo Dry Valleys, Antarctica. Arctic, Antarctic, and Alpine Research 40, 119-128, http://dx.doi.org/10.1657/ 1523-0430(06-051)[POAGE]2.0.CO;2.

Porazińska D.L., Fountain A.G., Nylen T.H., Tranter M., Virginia R.A. \& Wall D.H. 2004. The biodiversity and biogeochemistry of cryoconite holes from McMurdo Dry Valley glaciers, Antarctica. Arctic, Antarctic, and Alpine Research 36, 84-91, http://dx.doi.org/10.1657/15230430(2004)036[0084:TBABOC]2.0.CO;2.

Porazińska D.L., Wall D.H. \& Virginia R.A. 2002a. Invertebrates in ornithogenic soils on Ross Island, Antarctica. Polar Biology 25, 569-574, http://dx.doi.org/10.1007/s00300-002-0386-7.

Porazińska D.L., Wall D.H. \& Virginia R.A. 2002b. Population age structure of nematodes in the Antarctic Dry Valleys: perspectives on time, space, and habitat suitability. Arctic, Antarctic, and Alpine Research 34, 159-168, http://dx.doi. org/10.2307/1552467.

Pounds J.A., Fogden P.L. \& Campbell J.H. 1999. Biological response to climate change on a tropical mountain. Nature 398, 611-615, http://dx.doi.org/10.1038/19297.

Powers L.E., Freckman D.W., Ho M. \& Virginia R.A. 1995. McMurdo LTER: soil properties associated with nematode distribution along an elevational transect in Taylor Valley, Antarctica. Antarctic Journal of the United States 30, 282-287.

Powers L.E., Freckman D.W. \& Virginia R.A. 1994. Depth distribution of soil nematodes in Taylor Valley, Antarctica. Antarctic Journal of the United States 29, 175-176.

Powers L.E., Freckman D.W. \& Virginia R.A. 1995. Spatial distribution of nematodes in polar desert soils of Antarctica. Polar Biology 15, 325-333.

Powers L.E., Ho M.C., Freckman D.W. \& Virginia R.A. 1998. Distribution, community structure, and microhabitats of soil invertebrates along an elevational gradient in Taylor Valley, Antarctica. Arctic and Alpine Research 30, 133-141, http://dx.doi.org/10.2307/1552128.

Procter E.L.C. 1990. Global overview of the functional roles of soil-living nematodes in terrestrial communities and ecosystems. The Journal of Nematodology 22, 1-7.

$\mathrm{R}$ Development Core Team 2008. R: a language and environment for statistical computing. Vienna: R Foundation for Statistical Computing.

Ruprecht U., Lumbsch H., Brunauer G., Green T.G.A. \& Türk R. 2010. Diversity of Lecidea (Lecideaceae, Ascomycota) species revealed by molecular data and morphological characters. Antarctic Science 22, 727-741, http://dx.doi. org/10.1017/S0954102010000477.

Ruprecht U., Lumbsch H.T., Brunauer G., Green T.G.A. \& Türk R. 2012. Insights into the diversity of Lecanoraceae (Lecanorales, Ascomycota) in continental Antarctica (Ross Sea region). Nova Hedwigia 94, 287-306.

Sadaka N. \& Ponge J.F. 2003. Soil animal communities in holm oak forests: influence of horizon, altitude and year. European Journal of Soil Biology 39, 197-207, http://dx.doi. org/10.1016/j.ejsobi.2003.06.001.

Sawaske S.R. \& Freyberg D.L. 2015. Fog, fog drip, and streamflow in the Santa Cruz Mountains of the California Coast Range. Ecohydrology 8, 695-713, http://dx.doi. org/10.1002/eco.1537.

Scholl M.A., Giambelluca T.W., Gingerich S.B., Nullet M.A. \& Loope L.L. 2007. Cloud water in windward and leeward mountain forests: the stable isotope signature of orographic cloud water. Water Resources Research 43, W12411, http://dx.doi.org/10.1029/2007WR006011. 
Scott R.C. \& Lubin D. 2016. Unique manifestations of mixed-phase cloud microphysics over Ross Island and the Ross Ice Shelf, Antarctica. Geophysical Research Letter 43, 2936-2945, http://dx.doi.org/10.1002/2015 GL067246.

Shaw E.A., Adams B.J., Barrett J.E., Lyons W.B., Virginia R.A. \& Wall D.H. 2018. Stable isotopes reveal soil food web structure and the nematode, Eudorylaimus antarcticus, as an omnivore-predator in Taylor Valley, Antarctica. Polar Biology 41, 1013-1018, http://dx.doi.org/10.1007/ s00300-017-2243-8.

Stebaeva S. 2003. Collembolan communities of the UbsuNur Basin and adjacent mountains (Russia, Tuva). Pedobiologia 47, 341-356, http://dx.doi.org/10.1078/ 0031-4056-00198.

Storey B.C., Fink D., Hood D., Joy K., Shulmeister J., RigerKusk M. \& Stevens M.I. 2010. Cosmogenic nuclide exposure age constraints on the glacial history of the Lake Wellman area, Darwin Mountains, Antarctica. Antarctic Science 22, 603-618, http://dx.doi.org/10.1017/S09541020 10000799.

Wang S., Ruan H. \& Wang B. 2009. Effects of soil microarthropods on plant litter decomposition across an elevation gradient in the Wuyi Mountains. Soil Biology and Biochemistry 41, 891-897, http://dx.doi.org/10.1016/j.soilbio. 2008.12.016.

Timm R.W.1971. Antarctic soil and freshwater nematodes from the McMurdo Sound region. Proceedings of the Helminthological Society 38, 42-52.

Treonis A.M., Wall D.H. \& Virginia R.A. 1999. Invertebrate biodiversity in Antarctic Dry Valley soils and sediments. Ecosystems 2, 482-492, http://dx.doi.org/10.1007/s100219900096.

Vaughan D.G., Comiso J.C., Allison I., Carrasco J., Kaser G., Mote P., Murray T., Paul F., Ren J., Rignot E., Solomina O., Steffen K. \& Zhang T. 2013. Observations: cryosphere. In T.F. Stocker et al. (eds.): Contribution of Working Group I to the fifth assessment report of the Intergovernmental Panel on Climate Change. Pp. 317-382. Cambridge: Cambridge University Press.

Velasco-Castrillón A., Schultz M.B., Colombo F., Gibson J.A.E., Davies K.A., Austin A.D. \& Stevens M.I. 2014. Distribution and diversity of soil microfauna from East Antarctica: assessing the link between biotic and abiotic factors. PLoS One 9, e87529, https://doi.org/10.1371/ journal.pone.0087529.

Webster-Brown J., Gall M., Gibson J., Wood S. \& Hawes I. 2010. The biogeochemistry of meltwater habitats in the Darwin Glacier region $\left(80^{\circ} \mathrm{S}\right)$, Victoria Land, Antarctica. Antarctic Science 22, 646-661, http://dx.doi.org/10.1017/ S0954102010000787.

Wharton D.A., Marshall C.J. \& Egeter B. 2017. Comparisons between two Antarctic nematodes: cultured Panagrolaimus sp. DAWl and field-sourced Panagrolaimus davidi. Nematology 19, 533-542, http://dx.doi.org/ 10.1163/15685411-00003066.

Wolda H. 1987. Altitude, habitat and tropical insect diversity. Biological Journal of the Linnean Society 30, 313-323.

Wood T.G. 1974. The distribution of earthworms (Megascolecidae) in relation to soils, vegetation and altitude on the slopes of Mt Kosciusko, Australia. Journal of Animal Ecology 43, 87-106.

Zawierucha K., Buda J. \& Nawrot A. 2019. Extreme weather event results in the removal of invertebrates from cryoconite holes on an Arctic valley glacier (Longyearbreen, Svalbard). Ecological Research, http://dx.doi. org/10.1111/1440-1703.1276.

Zawierucha K., Smykla J., Michalczyk Ł., Gołdyn B. \& Kaczmarek Ł. 2015. Distribution and diversity of Tardigrada along altitudinal gradients in the Hornsund, Spitsbergen (Arctic). Polar Research 34, article no. 24168, http:// dx.doi.org/10.3402/polar.v34.24168.

Zibrodi G. \& Frezzotti M. 1996. Orographic clouds in north Victoria Land from AVHRR images. Polar Record 32, 317-324. 